\title{
Production of Extracellular Enzymes by Phytophthora palmivora (Butl.) Butl.
}

\author{
By O. A. AKINREFON \\ Long Ashton Research Station, University of Bristol \\ (Accepted for publication 7 September 1967)
}

\begin{abstract}
SUMMARY
Phytophthora palmivora is more exacting in its nutrition for extracellular enzyme production than for growth. All of thirteen defined media tested supported fairly good growth. The major enzymes detected were: endopolygalacturonase (endo-PG), maceration factor (MF), $\alpha$-L-arabinofuranosidase (AF) and phenolase. These enzymes were not detected in four of the five natural media tested. In egg-plant extract, traces of endo-PG, MF and pectinmethyl esterase were detected and higher activities of AF and phenolase produced. Inability to detect the enzymes in cultures in other plant extracts was possibly due to their inactivation by the oxidized phenols formed. The inability to detect other enzymes in cultures in defined media, especially those enzymes already implicated in plant diseases, may also be due to the fact that the media tested in the present work were not suitable for their induction. The most suitable basal medium for growth as well as good production of the major enzymes consisted of $(\%)$ : I, pectin; 2.5 , glucose; I, asparagine; $0.025, \mathrm{MgSO}_{4} \cdot 7 \mathrm{H}_{2} \mathrm{O} ; 0.5$, Difco yeast-extract; traces of thiamine.
\end{abstract}

\section{INTRODUCTION}

The fungus Phytophthora palmivora (Butl.) Butl. is one of the most common pathogens of a considerable number of tropical and subtropical plants in more than fifty genera (Hickman, I958). It causes wilt of the seedlings, different types of rot of the fruits and other effects. It is best known as a pathogen of cacao (Theobroma cacao L.) in which it causes pod rot, commonly called blackpod disease (Thorold, 1967). The first symptom of infection of cocoa pods is a small brown spot with an irregular somewhat water-soaked fringe, but quite firm in texture. The spot gradually increases in size within 3-4 days until the pod turns black and finally dries out. Since the symptom expression is quite different from that of a softer rot, such as that caused by Sclerotinia fructigena and Botrytis cinerea (Cole, 1956), elucidation of the role of the fungal enzymes in the physiology of the disease might be a useful contribution to the study of the parasitism of $P$. palmivora.

The processes of infection by Phytophthora palmivora have been shown on cacao (Orellana, I953; Spence, 196I), on Piper nigrum L. (Holliday \& Mowat, 1963), and its pathogenicity recorded on tomatoes (Weststeijn, 1964), on rubber (Peries, 1964) and on a wide range of hosts (Turner, 1960). The physiology of the fungus has also been extensively studied (Weststeijn, 1964; Peries, I964; Cameron \& Milbrath, I965; Roncadori, 1965). However, little is known about the physiological aspects of the disease and the role played by extracellular enzymes of the fungus. There is now evidence that cell-wall degrading enzymes play an important role when lesions are formed 
in plants by bacteria and fungi (Wood, 1959, I960; Brown, 1955, I965; Bateman \& Millar, 1966) and it seems, therefore, reasonable to assume that such enzymes may be active in the formation of rot incited by $P$. palmivora. Spence (I96I) suggested that pectic enzymes might be important in the host/parasite relations, although none of these enzymes were detected in the infected tissue and in the culture media tested. The present study was undertaken to examine the extracellular enzyme production by $P$. palmivora in a range of culture media.

\section{METHODS}

Chemicals. Brown Ribbon pectin (an apple pectin) was obtained from Union Crystalex Gelatin, England, and sodium polypectate (sodium ammonium pectate containing $4.2 \%$ sodium), and polygalacturonic acid from the Sunkist Growers Inc., California. Other chemicals used were sodium carboxylmethylcellulose (Cellofas B; I.C.I. Ltd.), $o$-nitrophenyl- $\beta$-D-galactopyranoside (L. Light, Ltd.), $p$-nitrophenyl$\alpha$-L-arabinofuranoside (supplied by A. H. Fielding, Long Ashton Research Station), charcoal gelatin disks(Oxoid), xylan(Nutritional Biochemicals Corporation, Cleveland, Ohio) and peanut meal (prepared as described by Tuttobello \& Mill, 196I).

Organisms. The isolates of Phytophthora numbered 63552, 63554, 79226, 79239 and 80298 were supplied by the Commonwealth Mycological Institute, Kew; isolates $\mathrm{S}-\mathrm{O}$ and NP I5 were from the culture collection of the Cocoa Research Institute of Nigeria, and the isolate 'COMUM' was supplied by G. Medeiros of the Cocoa Research Station, Bahia, Brazil. The isolates were all 'cocoa' types; all except 'CoMUM' were West African isolates.

Cultural methods. The cultures were maintained on oatmeal agar and stored at room temperature $\left(2 \mathrm{I}^{\circ}\right)$. The organism was sub-cultured on potato glucose agar (PGA) during the work reported here. To obtain inocula for growth experiments subcultures on the PGA plates incubated at $25^{\circ}$ for 7-10 days were used. Standard inoculum disks (one for every $5 \mathrm{ml}$. medium) were then cut with a no. I cork-borer from the advancing edge of the colony. Static cultures gave a more consistent result than shaken liquid cultures and were therefore preferred to the latter. The cultures were incubated for 7-10 days at $25^{\circ}$.

Culture media. These were tested for suitability to give good growth as well as for adequate enzyme production. Those previously tested by Spence (I96I) were not used.

Defined media. The following were tested:

(i) Per I00 ml.: glucose, I.0 g.; $\mathrm{KH}_{2} \mathrm{PO}_{4}$, 0.I g.; $\mathrm{MgSO}_{4} \cdot 7 \mathrm{H}_{2} \mathrm{O}$, 0.05 g.; $\mathrm{Ca}\left(\mathrm{NO}_{3}\right)_{2}$, I. ० g.; $\mathrm{Fe}\left(\mathrm{NH}_{4} \mathrm{SO}_{4}\right)_{2} .6 \mathrm{H}_{2} \mathrm{O}, 0.02 \mathrm{mg}$. $\mathrm{ZnSO}_{4} \cdot 6 \mathrm{H}_{2} \mathrm{O}, 0.02 \mathrm{mg}$.; $\mathrm{MnSO}_{4} \cdot 4 \mathrm{H}_{2} \mathrm{O}, 0.0 \mathrm{Img}$. (Roncadori, (1965), for the growth of Phytophthora species).

(ii) Per IOO ml.: sucrose, I.5 g.; pectin, I.5 g.; $\mathrm{KH}_{2} \mathrm{PO}_{4}$, 0.I g. $\mathrm{MgSO}_{4} \cdot 7 \mathrm{H}_{2} \mathrm{O}$, 0.05 g.; $\mathrm{FeSO}_{4} \cdot 7 \mathrm{H}_{2} \mathrm{O}$, 0.00I g. $\mathrm{KCl}, 0.05 \mathrm{~g}$; $\mathrm{NaNO}_{3}, 0.3 \mathrm{~g}$. (modified Czapek medium).

(iii) Per $100 \mathrm{ml}$.: glucose, $0.2 \mathrm{~g}$.; pectin, $2.5 \mathrm{~g}$.; $\mathrm{NH}_{4} \mathrm{NO}_{3}, 2.0 \mathrm{~g}$.; $\mathrm{MgSO}_{4} \cdot 7 \mathrm{H}_{2} \mathrm{O}$, $0.02 \mathrm{~g}$.; $\mathrm{KH}_{2} \mathrm{PO}_{4}$, I $\bullet 0 \mathrm{~g}$. (Pandey \& Gupta, (1966) for production of pectic enzymes by Alternaria tenuis).

(iv) Per $100 \mathrm{ml}$.: Glucose, 0.5 g.; pectin, $\mathrm{I} \cdot 0$ g.; asparagine, $0.4 \mathrm{~g}$.; $\mathrm{MgSO}_{4} \cdot 7 \mathrm{H}_{2} \mathrm{O}$, 0.05 g.; $\mathrm{KH}_{2} \mathrm{PO}_{4}, 0.1$ g. (Pandey \& Gupta, 1966).

(v) As in (iv) with $0.3 \mathrm{~g}$. $\mathrm{NaNO}_{3}$ replacing asparagine. 
(vi) As in (iv) with $\mathrm{I} \cdot 5 \mathrm{~g}$. glucose instead of $0.5 \mathrm{~g}$.

(vii) As in (vi) with $0.3 \mathrm{~g}$. $\mathrm{NaNO}_{3}$ for asparagine.

(viii) Per IOO ml.: pectin, I.6 g.; $\mathrm{NH}_{4}$ tartrate, ${ }^{\cdot} \cdot 5 \mathrm{~g}$.; $\mathrm{KH}_{2} \mathrm{PO}_{4}, 0 \cdot \mathrm{I}$ g.; $\mathrm{MgSO}_{4} \cdot 7 \mathrm{H}_{2} \mathrm{O}$, $0.05 \mathrm{~g}$. (Cole (1956) for Sclerotinia fructigena).

(ix) Per Ioo ml.: peanut meal extract, $2 \cdot 0 \mathrm{~g}$; $\mathrm{KNO}_{3}$, I.० g.; $\mathrm{KH}_{2} \mathrm{PO}_{4}, 0.5 \mathrm{~g}$; $\mathrm{MgSO}_{4} \cdot 7 \mathrm{H}_{2} \mathrm{O}, 0.25 \mathrm{~g}$. Difco yeast-extract, $0 . \mathrm{I}$ g. (Fuchs, Jobsen \& Wouts (I965) for production of arabanases by pathogenic fungi).

(x) As in (ix) with $2.0 \mathrm{~g}$. glucose replacing peanut meal extract.

(xi) Per I00 ml.: pectin, I.0 g.; asparagine, 0.I g.; $\mathrm{KH}_{2} \mathrm{PO}_{4}, 0.05$ g.; $\mathrm{MgSO}_{4} \cdot 7 \mathrm{H}_{2} \mathrm{O}$, $0.025 \mathrm{~g}$.; Difco yeast-extract, $0.5 \mathrm{~g}$.; thiamine, $0.000 \mathrm{I} \mathrm{g.} \mathrm{(Clarke} \mathrm{(1966)} \mathrm{for} \mathrm{production}$ of enzyme by Phytophthora infestans).

(xii) As in (xi) with 2.5 g. glucose replacing pectin.

(xiii) As in (xi) with $2.5 \mathrm{~g}$. glucose supplementing pectin.

Natural media. The following plant extracts were tested: tomato, potato, cocoa pod, eggplant; $200 \mathrm{~g}$. of each tissue were macerated in $\mathrm{r} 1$. water for $5 \mathrm{~min}$. in a Waring Blendor, and then strained through muslin. The cocoa-pulp extract was prepared by washing the beans from ripe pods in I l. water and then straining through muslin. The potato extract was used with or without glucose supplement. Portions of $25 \mathrm{ml}$. of each medium were dispensed in $6 \mathrm{oz}$. medicine bottles, and autoclaved at $12 \mathrm{I}^{\circ}$ for I5 min. after the $\mathrm{pH}$ had been recorded by glass electrode $\mathrm{pH}$ meter (Electronic Instruments Ltd., Richmond, Surrey).

Yield of organisms. Mycelium was harvested on a weighed Whatman no. 4I filter paper, washed with a small quantity of warm distilled water, heated overnight in an oven at about $90^{\circ}$, cooled in a desiccator and weighed. No further loss in weight was obtained by longer periods of drying.

Enzyme preparations. Crude culture filtrate obtained after harvesting mycelium was used as such for enzyme assays or was dialysed overnight against distilled water at $4^{\circ}$. The enzyme solution was stored at $4^{\circ}$ until used.

\section{Enzyme assays}

Boiled culture filtrate was used as a control in all assays.

Endo-polygalacturonase (endo- $P G$ ) was examined by the agar cup-plate diffusion technique as described by Dingle, Reid \& Solomons (1953). Pectinol-Io M standard solution (0.01 \%) was made the reference unit of 100.

Exo-polygalacturonase (exo-PG) activity was assessed by a colorimetric method described by Hancock \& Millar (1965), by measuring the rate of increase of galacturonic acid concentrations in enzyme substrate reaction mixtures, with dinitrosalicylic acid reagent at $575 \mathrm{~m} \mu$ extinction.

Pectin methyl esterase (PME) activity was determined by the titration method described by Smith (1958). The enzyme reaction resulted in increased acidity of the reaction mixture which was titrated back to the original $\mathrm{pH}$ value by standard alkali.

Polygalacturonate trans-eliminase (PTE) activity was determined by spectrophotometry as described by Hancock \& Millar (1965). The reaction mixtures contained I ml. culture filtrate, $4 \mathrm{ml}$. polygalacturonic acid or sodium polypectate solution $(0.25 \%)$ in 0. I M-tris- $\mathrm{HCl}$ buffer $(\mathrm{pH} 8.5)$, I ml. $\mathrm{CaCl}_{2}$ solution at final concentration $\mathrm{IO}^{-3} \mathrm{M}$. The liberation of unsaturated bonds during depolymerization of the pectate or polygalacturonic acid was followed at $230 \mathrm{~m} \mu$ with a spectrophotometer. 
The maceration $(M F)$ activity of the culture filtrate was assessed by a method similar to that of Brown (1915) and used by Cole (1956) and Byrde (1957). Cylinders of fully turgid potato-tuber tissue were cut with a no. 6 cork-borer, and disks $0.35 \mathrm{~mm}$. thick cut from these after injection with water under an air pump. Activity was estimated by placing four discs in the test solution and testing at intervals to determine the times at which coherence was lost when the discs were subjected to a gentle pull with two dissecting needles. The maceration activity of the preparation was defined as $100 / t$ where $t$ was the time (min.) for the discs to lose coherence.

$\alpha$-L-arabinofuranosidase $(A F)$ activity was determined by the colorimetric estimation of $p$-nitrophenol liberated from $p$-nitrophenyl- $\alpha$-L-arabinofuranoside (Fielding \& Hough, I965). The reaction mixture was made up of 0.25 to $\mathrm{I} \mathrm{ml}$. culture filtrate, $5 \mathrm{ml}$. acetate $(0 . \mathrm{I} \mathrm{M})$ buffer $(\mathrm{pH} 4.7), 0.5 \mathrm{ml}$. substrate solution $(0.5 \mathrm{mg} . / \mathrm{ml}$.). After $\mathrm{I} \mathrm{hr}$ at $25^{\circ}$, I ml. saturated $\mathrm{Na}_{2} \mathrm{CO}_{3}$ solution was added to stop the reaction and to develop the yellow colour. The Spekker readings were taken using a violet filter (Kodak no. 60I, wavelength $4300 \AA$ ). The activity was expressed in units $/ \mathrm{ml}$./hr as absorption readings after applying corrections for absorption of enzyme and substrate blanks respectively.

$\beta$-Galactosidase activity was also estimated by a colorimetric method similar to that described for AF, the substrate being $0.1 \% o$-nitrophenyl- $\beta$-D-galactopyranoside. A colorimetric method was used to assess polyphenolase activity, a modification of that described by Ponting \& Joslyn (1948). The reaction mixture contained I ml. culture filtrate, $4 \mathrm{ml}$. I \% pyrocatechol in McIlvaine's buffer (pH 7.0), $2 \mathrm{ml}$. distilled water. The reaction was stopped by adding a few drops of $\mathrm{N}-\mathrm{HCl}$. The brown colour intensity of the oxidized substrate was determined at $470 \mathrm{~m} \mu$ by Spekker absorptiometer.

Cellulase $(C x)$ was determined by a viscometric method: $\mathrm{I} \cdot 2 \%$ solution of sodium carboxymethyl cellulose in citric acid $\mathrm{NaOH}$ (Sørensen's citrate II) buffer (0.05 M) was used as the substrate.

Other assays for $\alpha$-amylase, protease, lecithinase and xylanase were by the agar cup-plate method as described for endo-PG activity, with soluble starch, gelatin, lecithin and xylan as substrates, respectively, in 0.2 M-acetate buffer (Dingle et al. 1953). The detection of protease activity was also attempted with charcoal gelatin disks as first described by Kohn (1953).

The cup-plate and PME assays were incubated at $25^{\circ}$ for $\mathrm{I} 8-24 \mathrm{~h}$.

\section{RESULTS}

\section{Enzyme production from growth in natural media}

Culture filtrates of Phytophthora palmivora isolate 63552 were tested for the activities of thirteen extracellular enzymes, most of which have been implicated in plant diseases. All the natural media were unsuitable for the production of the enzymes except $\alpha$-L-arabinofuranosidase $(A F)$ and phenolase. The addition of glucose to potato extract medium resulted in inhibition of production of all these enzymes. Similar inhibition of enzyme production in other fungi has been reported (Horton \& Keen, 1966; Husain \& Kelman, 1959).

A similar experiment was made to assess the suitability of these natural media for growth and enzyme production (PG, PME, AF and MF) of five isolates (nos. 63552, $63554,79239, \mathrm{~S}-\mathrm{O}$ and NP $\mathrm{I}_{5}$ ). Within the limits encountered, the $\mathrm{pH}$ values of the extracts did not appear to affect the growth of the isolates. Egg-plant fruit extract 
supported the best over-all growth (ranging from 50 to $77 \mathrm{mg}$.) and was also the best medium for AF production by all five isolates $(0.53$ to $0.67 \mathrm{units} / \mathrm{ml}$. $/ \mathrm{hr}$.) The isolate with the least growth produced the highest AF, and production of maceration factor MF) was not related to AF production, as suggested by Byrde \& Fielding (1965). In other extracts, traces of PME were generally detected, but PG was found only with isolate 63554 on cocoa pulp. Polygalacturonate trans-eliminase was one of the many enzymes not detected in these media.

Phenolase was detected in all the media except potato extract + glucose. The action of this enzyme accounted for the browning observed in most of the media and presumably the inhibition of the pectic enzymes.

All the media supported growth to a greater or less extent, potato extract gave the poorest growth of all isolates tested. When glucose was added to potato extract, however, growth was appreciably increased, but the only traces of enzyme detected were with isolates 79239 and s-0. In general, lack of enzyme production did not seem to restrict growth. The above results confirmed that different nutritional factors influenced growth and enzyme production by Phytophthora palmivora, and that the medium for best growth was not the most suitable for enzyme production.

\section{Enzyme production in defined media}

The culture filtrates of isolate $6355^{2}$ in defined media were examined for thirteen extracellular enzymes. All the media tested supported adequate growth. The following enzymes were not detected in the culture filtrates: PME, PMG, PGTE, $\beta$-galactosidase, $\alpha$-amylase, protease and lecithinase. The major enzymes detected were endo-PG, AF, MF and phenolase. Endo-PG was detected with all media; AF was detected in media iv, ix, xi and xiii, with traces in the remainder; MF was detected in media (iv) and (ix)-(xiii), with traces in (i), (ii), (iii) and (viii); phenolase was detected in media (ix)-(xiii), and $C x$ in medium (ix), with traces in (x)-(xiii). Traces of exo-PG were detected in media (ii) and (iii).

Suitability of defined media for production of the major enzymes by Phytophthora palmivora isolate 63554

All the defined media tested supported fairly good growth of isolate 63554 (Table r). The best medium for growth was again not necessarily the best for enzyme induction; media (xiii), (xi), (ix) and (xii) were the best (in that order) for growth; while the highest PG production was in media (ii), (vi), (vii), (ix) and (xiii).

The activities of the enzymes detected were not related to the growth yield of isolate $6355^{2}$, nor to the $\mathrm{pH}$ value of the media used.

\section{DISCUSSION}

From the previous work (Spence, I96I; Roncadori, 1965), it seems likely that Phytophthora palmivora is more exacting in its nutrition for enzyme production than for growth. The present study thus indicates that the media tested by Spence (I96I) were unsuitable for enzyme production, although these might have supported good growth. Not all the defined media tested in the present work gave production of the enzymes examined, although they all supported fairly good growth (Table I).

Although many fungal extracellular enzymes have been connected directly or indirectly with pathogenesis of plant diseases, only three major enzymes of the thirteen assayed could be detected; these were detected in culture filtrates of all isolates tested. 
Phenolase was also detected in the culture filtrates and may be important in plant infection and symptom expression (Deverall \& Wood, 196I; Oku, 1966). The three major enzymes were not detected in cultures grown on the natural media used, except traces of AF activity with isolate 63552 in potato and cocoa-shell extracts, and with isolates 63554 and 79239 in cocoa-shell extract. The absence of enzyme activity, except phenolase, in the natural media culture filtrate was probably due to inhibition by oxidized phenolics (Williams, 1963); most of the natural media turned brown. This may be the main factor for the absence of pectic enzymes in diseased tissues.

Table I. Comparative suitability of different synthetic media for growth and enzyme production of Phytophthora palmivora isolate 63554

(Averages of three determinations)

\begin{tabular}{|c|c|c|c|c|c|c|}
\hline \multirow[b]{2}{*}{ Media } & \multicolumn{2}{|c|}{$\mathrm{pH}$} & \multirow{2}{*}{$\begin{array}{c}\text { Dry wt. } \\
\text { (mg.) }\end{array}$} & \multicolumn{3}{|c|}{ Enzyme production* } \\
\hline & Initial & Final & & PG & $\mathrm{AF}$ & MF \\
\hline (i) & $4 \cdot 30$ & $4 \cdot 10$ & $4 \mathrm{I}$ & $2 I \cdot 9$ & 0.009 & 0 \\
\hline (ii) & $5 \cdot 50$ & $4 \cdot 40$ & 19 & $69 \cdot 2$ & 0.004 & 0 \\
\hline (iii) & $5 \cdot 10$ & $4 \cdot 75$ & 20 & $21 \cdot 9$ & 0 & 0 \\
\hline (iv) & $5 \cdot 35$ & $6 \cdot 85$ & 15 & $25 \cdot I$ & 0.031 & $I \cdot 5$ \\
\hline (v) & 5.55 & 4.50 & 20 & $39 \cdot 8$ & 0 & - \\
\hline (vi) & $5 \cdot 35$ & $6 \cdot 80$ & 29 & $39 \cdot 8$ & 0 & - \\
\hline (vii) & $5 \cdot 55$ & $4: 50$ & 18 & $25 \cdot I$ & 0 & - \\
\hline (viii) & $5 \cdot 80$ & $5 \cdot 50$ & 38 & 0 & 0 & 0 \\
\hline (ix) & 5.50 & $5 \cdot 50$ & 89 & $50 \cdot I$ & 0.002 & $I \cdot 9$ \\
\hline (x) & $4 \cdot 85$ & $4: 70$ & 66 & 14.5 & 0 & $1 \cdot 4$ \\
\hline (xi) & $4 \cdot 75$ & $4 \cdot 55$ & 106 & $31 \cdot 6$ & 0.104 & $1 \cdot 3$ \\
\hline (xii) & $5 \cdot 95$ & $4 \cdot 80$ & 82 & I5.9 & 0 & $I \cdot 6$ \\
\hline (xiii) & $4 \cdot 80$ & 4.90 & 130 & $39 \cdot 8$ & 0.184 & $I \cdot 2$ \\
\hline
\end{tabular}

Products of PG activity in some host-parasite relations activate the phenolase which in turn oxidize the host phenolic compounds; the latter inhibit the PG activity and the overall process results in lesion formation (Deverall \& Wood, I96I; Oku, 1966). Phenolase has been detected both in the culture filtrate of Phytophthora palmivora and in diseased tissues; a much lower activity was detectable in healthy plant extracts.

The detection of traces of pectin methyl-esterase in culture filtrates from natural media, particularly in eggplant extract, may be significant in the pathogenicity of the species. Clarke (1966) has suggested that this enzyme may be important in the hostparasite relationship of Phytophthora infestans, and Smith (1958) found indications that its production by various Xanthomonas species was correlated with their pathogenicity.

In conclusion, the best basal medium for the production of the major enzymes detected consisted of I $\%$ pectin, $2.5 \%$ glucose, I \% asparagine, $0.05 \% \mathrm{KH}_{2} \mathrm{PO}_{4}$, $0.025 \% \mathrm{MgSO}_{4} \cdot 7 \mathrm{H}_{2} \mathrm{O}, 0.5 \%$ Difco yeast extract and traces of thiamine.

The work in this paper was done under the kind supervision of Dr R. J. W. Byrde, and the author is grateful for his interest and the helpful criticism during the preparation of this manuscript. Thanks are also due to Professor H. G. H. Kearns for 
making available the research facilities on the Station; to Mr A. H. Fielding and Miss Celia Slowley for assistance, and the Cocoa Research Institute of Nigeria for financial support.

\section{REFERENCES}

Bateman, D. F. \& Millar, R. L. (1966). Pectic enzymes in tissue degradation. A. Rev. Phytopathol. 4, II9.

Brown, W. (1915). Studies in the physiology of parasitism. I. The action of Botrytis cinerea. Ann. Bot. 29, 3 I3.

Brown, W. (1955). On the physiology of parasitism in plants. Ann. appl. Biol. 48, 325 .

Brown, W. (1965). Toxins and cell wall dissolving enzymes in relation to plant disease. A. Rev. Phytopathol. 3, I.

BYRDE, R. J. W. (I957). The varietal resistance of fruits to brown rot. II. The nature of resistance in some varieties of cider apple. J. hort. Sci. 32, 227.

Byrde, R. J. W. \& Fielding, A. H. (I965). An extracellular $\alpha$-L-arabinofuranosidase secreted by Sclerotinia fructigena. Nature, Lond. 205, 390.

Cameron, H. V. \& Milbrath, G. M. (1965). Variability in the genus Phytophthora. I. Effects of nitrogen sources and $\mathrm{pH}$ on growth. Phytopathology $55,653$.

Clarke, D. D. (I966). Production of pectic enzymes by Phytophthora infestans. Nature, Lond. $21 \mathbf{1}$, 649.

Cole, J. S. (1956). Studies in the physiology of parasitism. XX. The pathogenicity of Botrytis cinerea, Sclerotinia fructigena, and $S$. laxa, with special reference to the part played by pectolytic enzymes. Ann. Bot. 20, 15.

Deverall, B. J. \& Wood, R. K. S. (I96I). Chocolate spot of beans Vicia faba L.-interactions between phenolase of host and pectic enzymes of the pathogen. Ann. appl. Biol. 49, 473.

Dingle, J., ReID, W. W. \& Solomons, G. L. (I953). The enzymic degradation of pectin and other polysaccharides. II. Application of the 'Cup-plate' assay to the estimation of enzymes. $J$. Sci. Fd Agric. 4, 149.

Fielding, A. H. \& Hough, L. (1965). The synthesis of $p$-nitrophenyl- $\alpha$-L-arabinofuranoside. Carbohydrate Res. I, 327.

Fuchs, A., Jobsen, J. A. \& Wouts, W. M. (1965). Arabanases in phytopathogenic fungi. Nature, Lond. 206, 7 I4.

HANCOCK, J. G. \& MillaR, R. L. (1965). Relative importance of polygalacturonate trans-eliminase and other pectolytic enzymes in Southern anthracnose, spring black stem, and Stemphylium leaf spot of alfalfa. Phytopathology 55, 346.

Hickman, C. J. (I958). Phytophthora-plant destroyer. Trans. Br. mycol. Soc. 4r, I.

Holliday, P. \& Mowat, W. P. (1963). Foot-rot of Piper nigrum L. caused by Phytophthora palmivora (Butl.) Butl. Phytopath. Pap.No. 5.

Horton, J. C. \& KeEN, N. T. (1966). Sugar repression of endo-polygalacturonase and cellulase synthesis during pathogenesis by Pyrenochaeta terrestris as a resistance mechanism of onion pink rot. Phytopathology 56, 908.

Husain, A. \& Kelman, A. (1959). Tissue is disintegrated. In Plant Pathology. Ed. by J. G. Horsfall and A. E. Dimond. Vol. I. New York: Academic Press.

KoHN, J. (I953). A preliminary report of a new gelatin liquefaction method. J. clin. Path. 6, 249.

$\mathrm{OKU}, \mathrm{H}$. (1966). Host-parasite relation in Helminthosporium leafspot disease of rice plant from the viewpoint of biochemical nature of the disease. In Host-parasite relations in plant pathology Symp. Hung. Acad. Sci., p. 183.

Orellana, R. G. (1953). Infection and tissue changes of Theobroma cacao L. by Phytophthora palmivora (Butl.). Turrialba 3, 167.

PANDEY, D. K. \& Gupta, S. C. (1966). Studies in pectic enzymes of parasitic fungi. VI. Factors affecting the secretion of pectic enzymes by Alternaria tenuis. Biologia Pl. 8, I 31 .

Peries, O. S. (1964). Physiology of Phytophthora palmivora. A. Rev. Rubb. Res. Inst., Ceylon, p. 48.

Ponting, J. D. \& Joslyn, M. A. (1948). Ascorbic acid oxidation and browning in apple tissue extracts. Arch. Biochem. Biophys. 19, 473.

RonCADORI, R. W. (I965). A nutritional comparison of some species of Phytophthora. Phytopathology $55,595$. 
SMITH, W. K. (1958). A survey of the production of pectic enzymes by plant pathogenic and other bacteria. J. gen. Microbiol. 18, 33.

SPENCE, J. A. (1961). Blackpod disease of cocoa: A study in host-parasite relations. Ph.D. Thesis, University of Bristol.

THOROLD, C. A. (1967). Blackpod disease of Theobroma cacao. L. Rev. appl. Mycol. 46, 225.

TURNER, P. D. (1960). Strains of Phytophthora palmivora. Rep. W. Afr. Cocoa Res. Inst. 1958/59, p. 27.

TutToBello, R. \& Mill, P. J. (I96I). The pectic enzymes of Aspergillus niger. I. The production of active mixtures of pectic enzymes. Biochem. J. 79, 51 .

Weststeisn, G. (1964). Strains of Phytophthora palmivora. Rep. W. Afr. Cocoa Res. Inst. 1962/63, p. 34 .

WiLliams, A. H. (1963). Enzyme inhibition by phenolic compounds. In Enzyme Chemistry of Phenolic Compounds. Ed. by J. B. Pridham, p. 87. Oxford: Pergamon Press.

Wood, R. K. S. (1959). Pathogen factors in the physiology of disease: Pectic enzymes. In Plant Pathology-Problems and Progress, 1908-1958. Ed. by C. S. Holton et al. p. 100. Madison: Univ. Wisconsin Press.

Wood, R. K. S. (1960). Pectic and cellulolytic enzymes in plant diseases. A. Rev. Plant. Physiol. Ir, 299. 